Journal of Early Childhood Care E Education
JECCE
ISSN : 2615-1413 (online)
http://journal2.uad.ac.id/index.php/jecce

\title{
RETRACTED: PERBEDAAN KREATIVITAS ANAK KELOMPOK A ANTARA KEGIATAN KOLASE BAHAN ALAM DAN KOLASE BAHAN KERTAS
}

\section{Sri Widayati, Nurhenti Simatupang, Kartika Rinakit Adhe, Nurul Ulfatul Hasanah}

Universitas Negeri Surabaya, Fakultas Ilmu Pendidikan

sriwidayati@unesa.ac.id, nurhentidorlina@unesa.ac.id, kartikadhe@unesa.ac.id, nurululfatul@unesa.ac.id

\begin{tabular}{l}
\hline Info Artikel \\
\hline Perbedaan Kreativitas Anak \\
Kelompok A Antara \\
Kegiatan Kolase Bahan \\
Alam dan Kolase Bahan \\
Kertas Vol 2, No 1, pp. 21- \\
29, March 2019
\end{tabular}
Abstrak
Following a rigorous, carefully concerns and considered review of the article published in JECCE (Journal of Early Childhood Education and Care) to article entitled : Perbedaan Kreativitas Anak Kelompok A Antara Kegiatan Kolase Bahan Alam dan Kolase Bahan Kertas Vol 2, No 1, pp. 21-29, March 2019,

This paper has been found to be in violation of the JECCE Publication principles and has been retracted.

The article contained redundant material, the editor investigated and found that the paper published in Jurnal PAUD Teratai, Vol. 7, No. 3, pp. 1-6, 2018.

The document and its content has been removed from JECCE, and reasonable effort should be made to remove all references to this article.

Keywords:

Copyright (C) 2018 JECCE, Universitas Ahmad Dahlan

$\triangle$ Alamat korespondensi: 